Article

\title{
How do East and Southeast Asian Cities Differ from Western Cities? A Systematic Review of the Urban Form Characteristics
}

\author{
Tzu-Ling Chen ${ }^{1, *}$, Hao-Wei Chiu ${ }^{2,3}$ and Yu-Fang Lin 4 \\ 1 Department of Urban Development, University of Taipei, Taipei 11153, Taiwan \\ 2 Department of Bioenvironmental Systems Engineering, National Taiwan University, Taipei 10617, Taiwan; \\ haoweichiu@gmail.com \\ 3 Graduate Institute of Urban Planning, National Taipei University, New Taipei 23741, Taiwan \\ 4 Department of Landscape Architecture, National Chiayi University, Chiayi 60004, Taiwan; v.yflin@gmail.com \\ * Correspondence: skylight@mail2000.com.tw; Tel.: +886-02-2871-8288 (ext. 3110)
}

Received: 11 February 2020; Accepted: 17 March 2020; Published: 19 March 2020

check for updates

\begin{abstract}
The Fifth Assessment Report released by the Intergovernmental Panel on Climate Change (IPCC AR5) revealed that the scale of greenhouse gas (GHG) emissions in Asian cities is similar to those from developed economies, which are driven predominantly by economic growth. Due to variations in geographic and climatic contexts, culture and religion, living style and travel behavior, governance and institutions, and a wide range of density and land use mixes, there are significant variations in urban form patterns across Western and Asian cities. This paper uses a systematic review, which is a critical interpretive synthesis methodology, to review keywords of studies related to urban form among East and Southeast Asian cities. From 3725 records identified through database searching, 213 studies were included in qualitative analysis. The results show that, although the population density in built-up areas is higher, annual population density is declining significantly in East and Southeast Asia. In addition, there are various kinds of land use mixes including horizontal, vertical, and temporal forms. As a whole, the inconsistencies of urban form characteristics exist not only between Western and Asian cities, but also among Asian cities. Serious population density decreases in Asian cities might indicate that they are undergoing similar urban development processes to those of Western cities. We should be aware of the potential lock-in trends of urban development patterns in Chinese and Southeast Asian cities.
\end{abstract}

Keywords: density; land-use mix; systematic review; Asian cities; urban form; urban development

\section{Introduction}

Climate change has become one of the most challenging global issues, and the issue calls for a global response. There are several phenomena that have recently occurred and provided physical evidence of climate change (e.g., global warming, extreme events). The Fourth Assessment Report of the Intergovernmental Panel on Climate Change (IPCC AR4) concludes that human activities, such as the combustion of energy consumption and land use changes, are "very likely" to be the cause of global warming, and that approximately $77 \%$ of the anthropogenic Greenhouse Gas (GHG) emissions affect the long term warming trend [1]. In addition, cities play a crucial role in climate change due to increasing pressure from the trend of rising populations, economic development, and built-environment concentration in urban areas. The latest IPCC report (IPCC AR5) further addressed a key message that urban areas are the main areas of global energy consumption and GHG emissions, which were mainly consumed in the sectors of infrastructure and transportation [2]. While urban 
sprawl has been recognized as being responsible for three-quarters of GHG emissions, it is essential to estimate and attempt to reduce GHG emissions from urbanization dynamics.

At the regional scale, the $\mathrm{CO}_{2}$ intensity of energy consumption increased by $44 \%$ between 1970 and 2010, while a steady growth in Gross Domestic Product (GDP) per capita combined with its population growth has been the most significant factor behind the increase in GHG emissions in Asia during this period [2]. The $\mathrm{CO}_{2}$ emissions from consumption by Asia increased by $175 \%$ from booming Asian economies during the 1990-2010 period. Over the last two decades, 1\% of world GDP increase has been accompanied by a $0.49 \%$ increase in fossil energy $\mathrm{CO}_{2}$ emission due to the rapid growth of the energy-intensive economy in non-Organization for Economic Co-operation and Development (OECD) Asian countries. These trends raise concerns about declining GHG emissions in high-emission regions combined with relatively fast population and economic growth in Asia [2].

To respond to the challenge of climate change, the IPCC has proposed that certain urban form characteristics, which have been identified as density, mixed land use, connectivity and accessibility, could help reduce $\mathrm{CO}_{2}$ emissions. Accordingly, the integrated strategies of climate change mitigation can be implemented by using spatial planning, transportation development and urban design in cities $[2,3]$. The strategies of density, mixed land use, connectivity and accessibility have been implemented in the United States [4], Canada [5,6], and the United Kingdom [7] via increasing population density, work track employment density, land-use mix, public transit accessibility, and others. Indeed, the spatial arrangements of land use, transportation systems, and urban design elements shape the urban form and could further mitigate $\mathrm{CO}_{2}$ emissions.

Though a large number of existing studies provide evidence to support various combinations of such metrics of urban form, most studies are discussed from a North American cities perspective and are mainly focused on larger cities [2]. However, Asian cities have practiced compact development with high density and mixed land use for a long time. In fact, compact development may not necessarily be suited to the context of Asian countries, especially in developing countries [8-10]. There is a lack of knowledge and understanding of urban patterns regarding Asian cities. Meanwhile, urbanization will be especially obvious in developing countries, and future population growth will especially aggregate in Asian cities. There will be a 37\% urban population increment mostly in Eastern Asia (EA) [11], especially in China and Indonesia, which increases the demand for a comprehensive survey regarding climate change mitigation and urban patterns for Asian cities.

It is, therefore, necessary to understand the urban form characteristics in the planning context of Asian cities, and also to discuss the differences of urban form characteristics between Asian and Western cities. Furthermore, the similarities and differences of urban form characteristics between Eastern and Southeast Asian (SEA) cities will then be discussed, to try and avoid lock-in problems while moving forward with urban development. The research questions are formulated as follows: (1) What are the specific features of urban form in particular density and land-use mix among Asian cities? (2) What are the similarities and differences of urban form characteristics among East and Southeast Asian cities?

The systematic review approach and search and selection criteria are illustrated in Section 2. In Section 3, the search results are discussed, including the description of case studies and the tendency and frequency of relevant research in East and Southeast Asian cities. The paper then discusses the characteristics which form density patterns and land use mix (diversity) patterns in Section 4. In Section 5, there is a comparison of population density, economic status, energy consumption, and GHG emissions by region as well as urban form, the planning system, and developing periods in EA and SEA. The paper concludes with the findings and implications in Section 6.

\section{Materials and Methods}

\subsection{Explanation of Variables and Concepts}

The primary variables and concepts used in this paper regarding urban form and systematic review are described in this section. According to the IPCC AR5 report, the urban form can be 
categorized into four key metrics, namely, density, land-use mix, connectivity, and accessibility. Density is the measure of an urban unit of interest and common measures are population, built-up area, and employment per unit area [12]. Land use mix is a measurement of the diversity and integration of land uses at a given scale and common measures include the ratio of jobs to residents, the variety and mixture of amenities and activities, and the relative proportion of retail and housing [13]. Connectivity is a measurement of street density and design and common measures are intersection density, block size, and intersections per $\mathrm{km}$ of road [14]. Accessibility is a measurement of access to jobs, housing, and services while common accessibility measures are job accessibility by auto or transit, distance to the city center, and retail accessibility [15]. As the calculation of connectivity and accessibility might vary among countries, this study only applied a basic comparative analysis to all four characteristics. This study only abstracted data of density and standardized it to complete the further discussion.

A systematic review is based on systematic and explicit methods to collect, identify, and analyze data from studies [16]. Statistical methods may or may not be applied to either analyze or summarize the data [17]. The systematic review is guided by the PRISMA Statement (Preferred Reporting Items for Systematic reviews and Meta-Analyses) [18]. The advantages of applying a systematic review include defining clear questions, identifying inclusion and exclusion criteria, and examining a large database of scientific literature in a defined time [19].

\subsection{Systematic Review Approach}

This paper used the systematic review to synthesize findings of urban form characteristics studies in East and Southeast Asia. A systematic review collates all empirical evidence to answer a specific research question that uses systematic methods to identify, select, and assess all the relevant studies and to synthesize the characteristics and findings from the research $[18,20]$. Therefore, this article employs the systematic review to identify, select, and critically appraise relevant research of urban form characteristics, in particular focusing on density and land use mix in East and Southeast Asian cities, and to collect and analyze data from studies and other databases that were included in the review.

\subsection{Search and Selection Criteria}

Two electronic databases (Web of Science and Scopus) have been searched thoroughly from January 1965 to December 2019. Two categories of search terms were used: "Country" AND ("urban form" OR "urban structure" OR "urban pattern" OR "spatial structure") and "Country" AND "urban" AND "measurement of urban form" (see Table 1). The search term of "Country" was based upon our requirement in this study to include East Asian and Southeast Asian cities. Moreover, the search terms of "measurement of urban form" was based upon IPCC AR5 and included "density", "land-use mix", "connectivity", and "accessibility." In addition, the following four principles were proposed in this study to complete the whole systematic review process.

(1) The article must analyze or discuss any urban form characteristics in East or Southeast Asia cities;

(2) The predefined keywords should exist as a whole in at least one of the fields: title, keywords or abstract;

(3) The paper should be published in a scientific peer-reviewed journal on the Web of Science and Scopus, and provide electronic full-text; and

(4) The paper should be published in the English language.

The searching process in system review included identification, screening, eligibility and included (see Figure 1). In the first results, there were 3725 records identified through database searching. In the next steps, articles without the full-text or inconsistency with the theme were then excluded and the number of remaining articles was 306. Thirdly, 93 articles were excluded for being duplicates. Therefore, 213 articles were included in the systematic review. The numbers of selected samples, as well as the discussing topics and metrics, are shown in the next section. Accordingly, this paper 
extracted data from the selected samples, and discusses the key findings of urban form characteristics in Eastern and Southeast Asian cities separately.

Table 1. Search criteria for the literature review.

\begin{tabular}{|c|c|}
\hline Type & Keywords \\
\hline Country/Region & $\begin{array}{l}\text { China, Hong Kong, Macau, Japan, North Korea, South Korea, Mongolia, Taiwan, } \\
\text { Indonesia, Malaysia, Philippines, Singapore, Thailand, Vietnam }\end{array}$ \\
\hline $\begin{array}{l}\text { Measurement of } \\
\text { urban form }\end{array}$ & $\begin{array}{l}\text { "density" OR "population density" OR “job density" } \\
\text { "land use mixed" OR "land use texture" OR "land use configuration" OR "mixed land use" } \\
\text { "connectivity" OR "street network" OR "street node" OR “intersection density" } \\
\text { "accessibility" OR "walk score" OR "walkability" }\end{array}$ \\
\hline
\end{tabular}

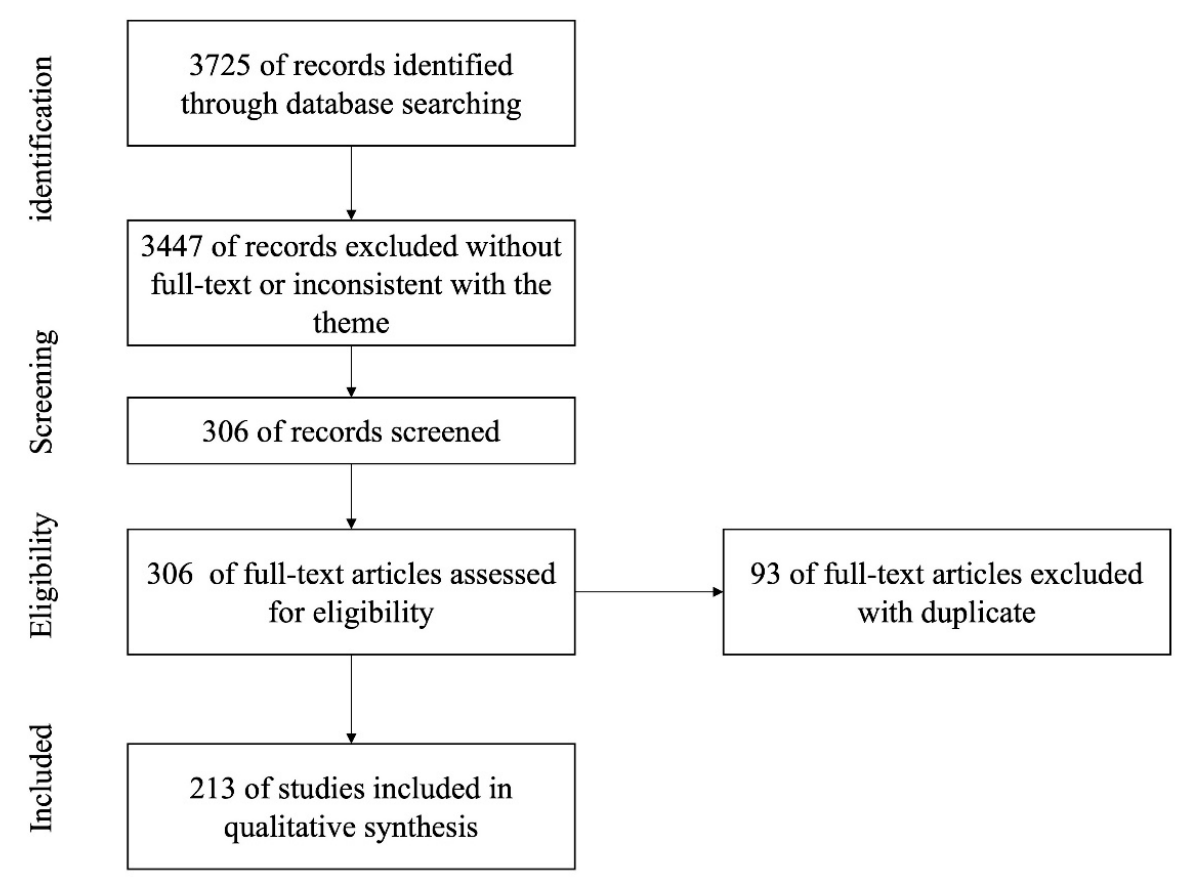

Figure 1. Flow of information through the different phases of a systematic review.

\subsection{Data Extraction}

The study has synthesized the studies and calculated three measures of urban form characteristics in East and Southeast Asia: (1) total area extent of population density (people/ha) and built-up density (ha) between 1990 and 2019. The study extracted and analyzed measures of urban form characteristics from the individual case studies. Population density was calculated based on the common density measurement, i.e., people per hectare in this study.

\section{Search Results}

\subsection{Description of Case Studies}

A total of 213 articles covered 15 countries/regions and 323 cities in East and Southeast Asia; they were mostly focused on Northeast Asia, including China, Japan, Korea, and Hong Kong. In addition, the cities which have been discussed are mainly capitals and megacities. Figure 2 displays the number of references by country. In the selected samples, some articles only discussed a single city, while some articles compared and discussed more than 20 cities in one study. More than half of the reference papers focused on China (101), and the other popular countries/areas were Hong Kong (41), Japan (28), and South Korea (21) (see Figure 2A). These selected samples paid more attention to Eastern Asia, such 
as Japanese cities (155), Korean cities (79), and Chinese cities (63), and most studies discussed Hong Kong (41), Beijing (37), Shanghai (18), Guangzhou (17), and Seoul (15) (see Figure 2B).
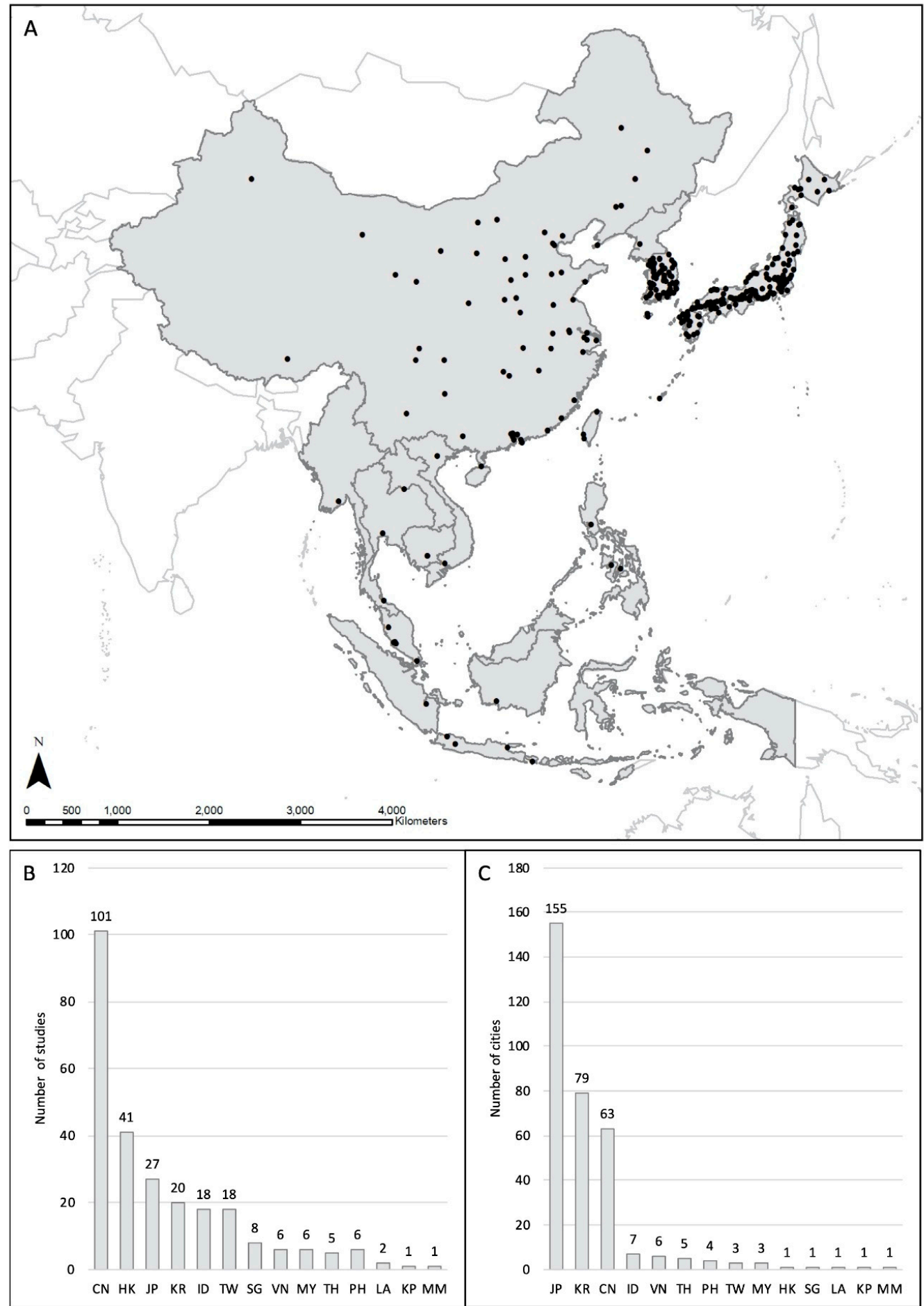

Figure 2. Geographical distribution of case studies and their locations. (A) Location of case studies. (B) Studies by country. Numbers in parentheses are the number of reference papers for each country. (C) Reference cities by country. Numbers in parentheses are the number of cities for each country (Total: 323 cities). Note: Country code (ISO3166-1) of case studies: CN-China, HK-Hong Kong, ID—Indonesia, JP—Japan, KH—Cambodia, KP-North Korea, KR-South Korea, LA—Laos, MM-Myanmar, MY-Malaysia, PH-Philippines, SG-Singapore, TH-Thailand, TW-Taiwan, VN-Vietnam). 
The academic field is starting to become aware of the importance of medium- and small-size cities. However, due to their developed status and reputation, $83 \%$ of selected samples are capital cities and megacities, which have been conducted on either a single city, a cross-cities comparison within Asia, or a cross-cities comparison between Asia and the West. Fewer studies focus on medium- and small-size cities and the capitals in Southeast Asian countries. Therefore, there is less understanding or even a knowledge gap of the urban form characteristics in those medium- and small-size cities and Southeast Asian cities. It seems that there are a lot of unknown urban form characteristics in the Asian context, which is constructed of diverse cultural, institutional, and societal norms that differ from Western cities. Therefore, it is essential to understand the urban patterns and a comprehensive discussion is needed regarding the rapidly urbanizing areas in Asia.

\subsection{Tendency and Frequency of Relevant Research in East and Southeast Asian Cities}

The urban form characteristic that has been discussed most frequently in research articles is "density" (Figure 3). Comparing the discussion on urban form characteristics by a single city, Hong Kong is the most popular with 86 papers (density: 24; land-use mix: 14; connectivity: 20; accessibility: 28). The next most commonly studied cities are Beijing, Seoul, Shanghai, Guangzhou, Tokyo, Nanjing, and Taipei.

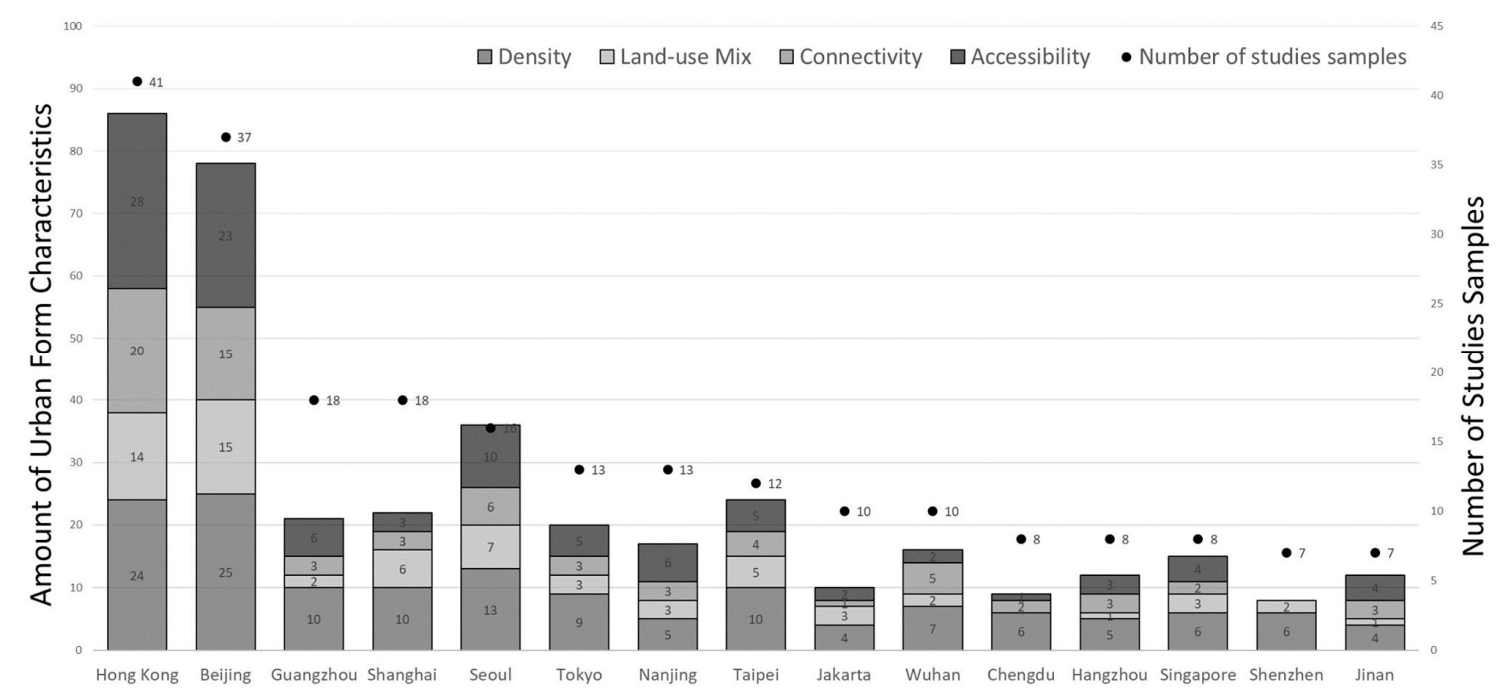

Figure 3. Urban form characteristics discussion in the 15 most commonly studied Asian cities.

The selected samples were mainly published in four journals: Habitat International (24), Cities (12), Landscape and Urban Planning (12), and Journal of Transport Geography (10) (see Figure 4A). Moreover, the most discussed journal subjects were environmental studies (52), urban studies (52), geography (32), transportation (30), planning and development (20), and environmental sciences (19) (see Figure 4B). Looking at research trends over time, there were fewer studies regarding urban form characteristics published between 1990 and 2000, and more studies discussed urban patterns in East and Southeast Asia since 2000. A dramatic increase appeared from 2006 to 2015; subsequently, there was a drop from 2016 to 2019. The continued growth of publishing papers represents the increasing attention to urban form characteristics in Asian cities. 


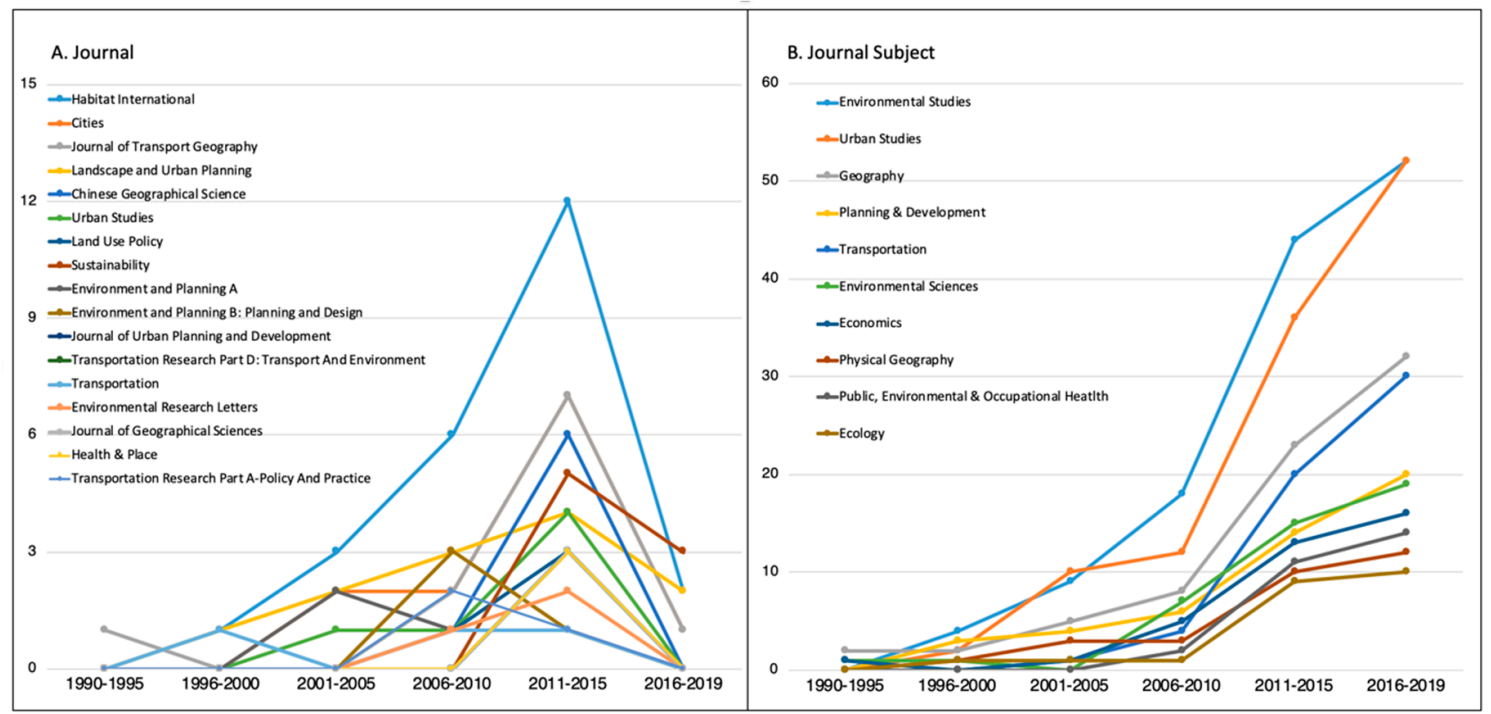

Figure 4. The research trends of urban form characteristics by journal name (A) and journal subject (B).

\section{Results: Characteristics of Studies}

Urban form characteristics based on varied dimensions impacts GHGs emissions differently. Therefore, the definition of each urban form characteristic should be added before discussing the characteristics of studies. Density is a measure of a unit of interest (e.g., population, employment, housing, and floor space) per unit area (e.g., city, metro area, and nation). The measurement of land-use mix is based on the diversity and integration of land uses at a given scale. Connectivity can be measured according to street density and design. Accessibility is measured based on the combination of proximity and travel time [2]. Due to the limited data from selected samples, the urban patterns in East and Southeast Asian cities are only shown in terms of density and land use mix as follows.

\subsection{Density Patterns}

Density value is one of the most common interpretations of the urban form [21], and density measurement can be divided into several perspectives including population density [22], built-up density [23], building density [24], and neighborhood density. Population density is calculated based on the common density measurement, i.e., persons per hectare in this study. In this article, we discuss not only population density at a given time-point and unit, but also the change between two specific times and two units, which are administrative boundary and built-up area (see Figure 5).

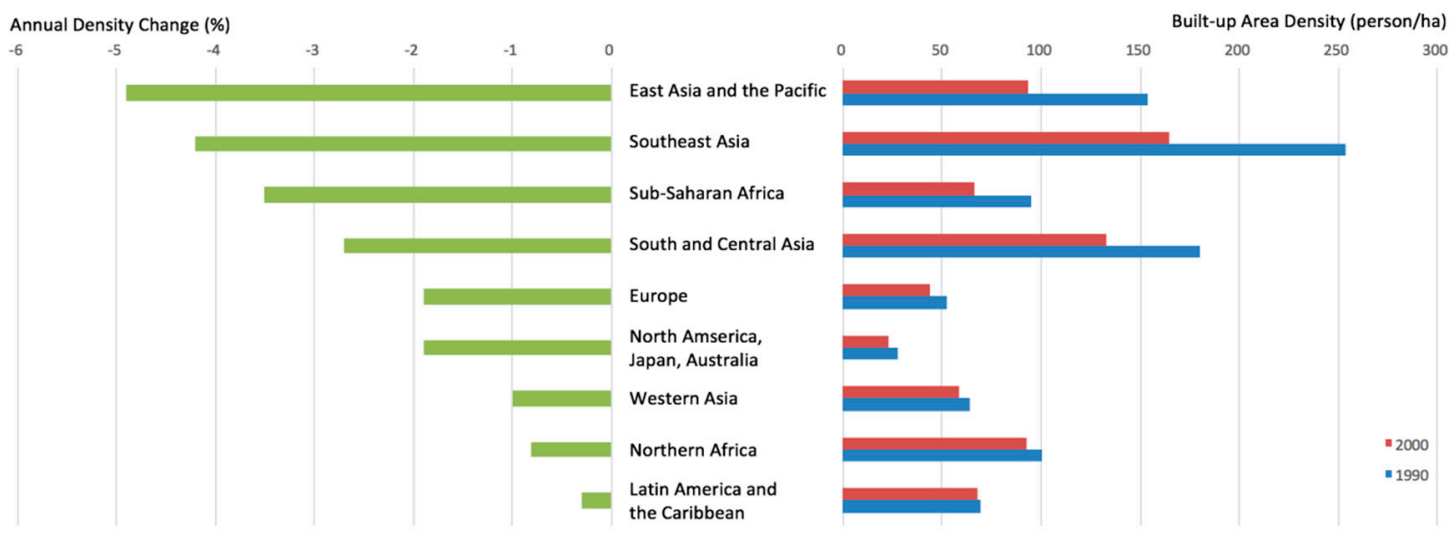

Figure 5. Comparison of density patterns by region (References [2]). 
Most developing cities have a higher population concentration in the historical urban center and maintain mono-centric urban forms due to the long-term planning policies such as Bandung [8], Bangkok [25], Nanjing [26], Guangzhou [27], Beijing [27], Shanghai [27], Kunming [28], Wuhan [28], Xi'an [28], Shenyang [29], Ho Chi Ming City [30], and Hong Kong [9]. However, some East and Southeast Asian cities typically undergo some decrease in population density in the core during their development trajectory [31,32]. The population density declined gradually in the core area of these cities. In contrast, the density of the sub-districts close to the core continued to rise and gradually spread towards the edge of the built-up area (e.g., Beijing, Shanghai, and Hangzhou) due to the thinning out of residential activities from the city center, giving way to commercial activities [26,28,31]. Another type of urban form is found in Hong Kong and Seoul, where the traditional urban core has the highest density, and the new growth areas have the fastest population growth [33,34].

Two distinct trends of population density in the district and built-up area are apparent (See Figure 6, the black line vs. the red line). First, the population densities in the built-up area in Hong Kong, Seoul, Singapore, Tokyo, Ho Chi Minh City, Jakarta, Manila, and others are higher than the densities in the district. Hong Kong is well known for its enormous population pressure and limited supply of flat land, and the high population density value is located in the existing development area [35]. Most Southeast Asian cities are in the dramatically urbanized stage, and the population has aggregated into urban areas significantly in those cities such that the built-up density is reaching 500 per/ha in Ho Chi Minh City, which is 2.5-fold the district population density. The second trend of population density in Chinese cities is similar in both the district and the built-up areas because state control plays an important role in shaping cities and guiding population density distribution [36,37]. 


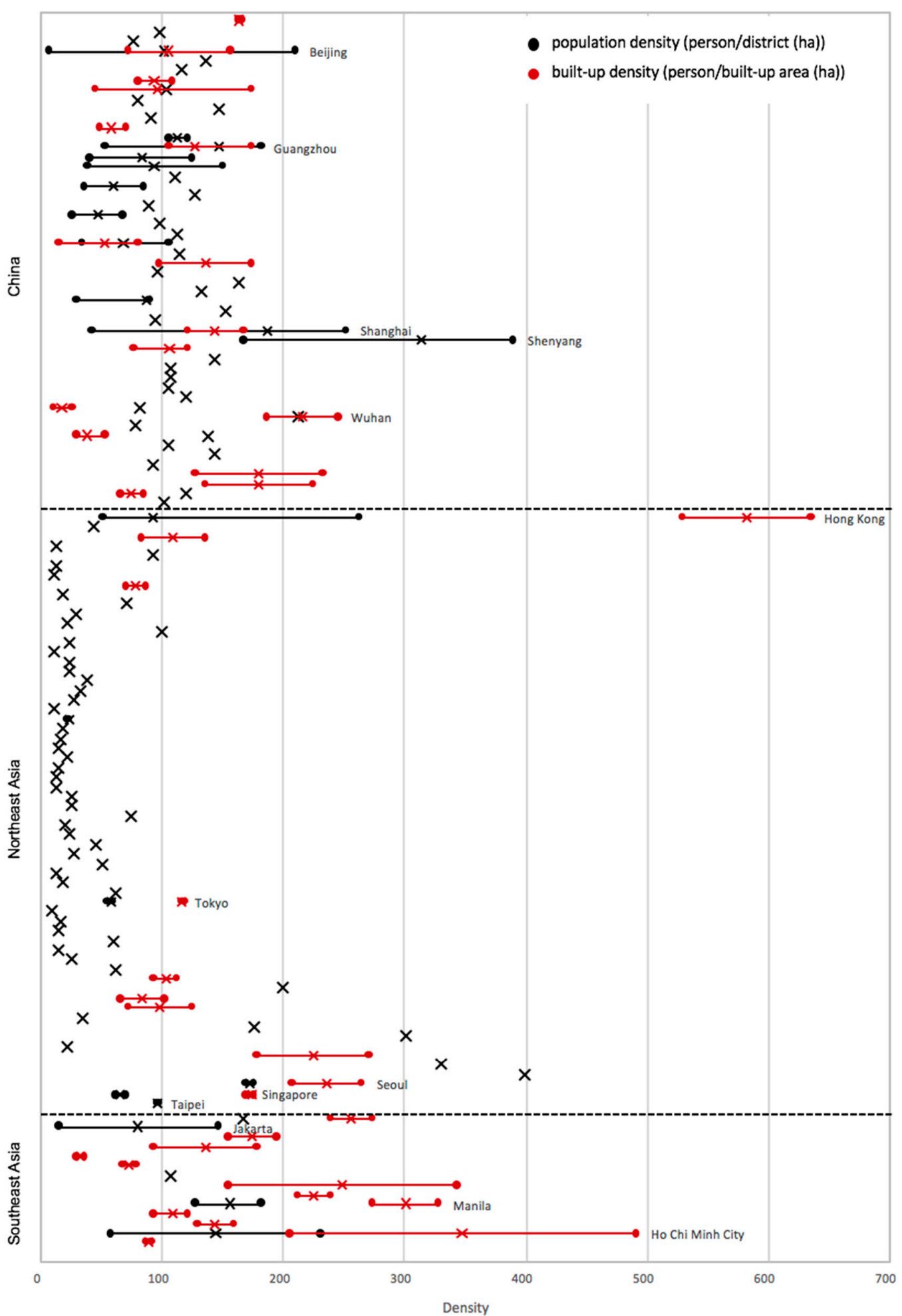

Figure 6. Density patterns in East Asian and Southeast Asian cities (References [8-10,27,29,30,34,37-66].

\subsection{Land-Use Mix (Diversity) Patterns}

Mixed land use in Asian societies has a notable difference compared with separated land uses in Western countries because of different cultural and social backgrounds [37]. For the functions of living and production (work and retail), the traditional urban agglomerations of Asian cities show mixed land uses ubiquitously. The land use mix in East Asian cities refers to the residence-employment mix of land use varieties, with different types (residential, industrial, commercial, open space, infrastructure, 
government, institution, and community facilities) for different activities (e.g., residential and industrial uses), facilities (e.g., mixture of schools and parks), or functions (e.g., residential areas mix with retail stores and schools) $[9,38,67-70]$. The zoning ordinance is accordingly based on a mixed-use structure in most Asian countries; the most urbanized land in Asian cities is moderately or heavily mixed use. For instance, the ordinance of Taipei city contains 56 land use types and 12 land use zones, and each land use zone permits more than 10 types [38,71]. The residential area permits land-use types that are not only a purely residential area with a single-family house, but also contains community facilities, educational facilities, agriculture, public facilities, and retail [72]. However, cities in Southeast Asia display a low mixture of land uses, since the land uses were usually dominated by either workplaces or residential areas. For instance, the suburbs are mostly dominated by residential areas in Jakarta [39,40,73-75].

Cities growing more upward than outward is the notable characteristics in East and Southeast Asian cities, while Chinese cities have both upward and outward features [76]. Therefore, the mixture of land uses in Asian cities does not only refer to horizontal land use mix, but also to vertical mixed land use, which relates to multi-purpose use (e.g., residential-commercial mixed use) in a single building (Figure 7). In Asia, the vertical mix of use has occurred in many cities such as Hong Kong [38,77,78], Taipei [79,80], Tokyo [41,81], and Seoul [82]. The typical horizontal mixed land use means zoning, which includes different types of residential area, industrial area, commercial area, and green area in the same area at a given scale. The vertical mixture of land use in Asian cities is a general building use pattern due to high-rise buildings. Moreover, unofficial economics and street market displays are an example of the temporal mixture of land uses (e.g., vendors of breakfast and snacks at a different time) [73] (Figure 7). In terms of the temporal mixture, land use diversity refers to different land uses in the same space at different periods. For instance, Figure 7 shows a land use mix of horizontal, vertical, and temporal types in Asian cities, here we use an example in Taiwan to show such horizontal, vertical, and temporal land use mix patterns. Even if the horizontal land zoning is shown as a residential zone, it may be a residential and commercial mix from the vertical perspective. Moreover, there might be different unofficial economic uses at different times in one vacant area.

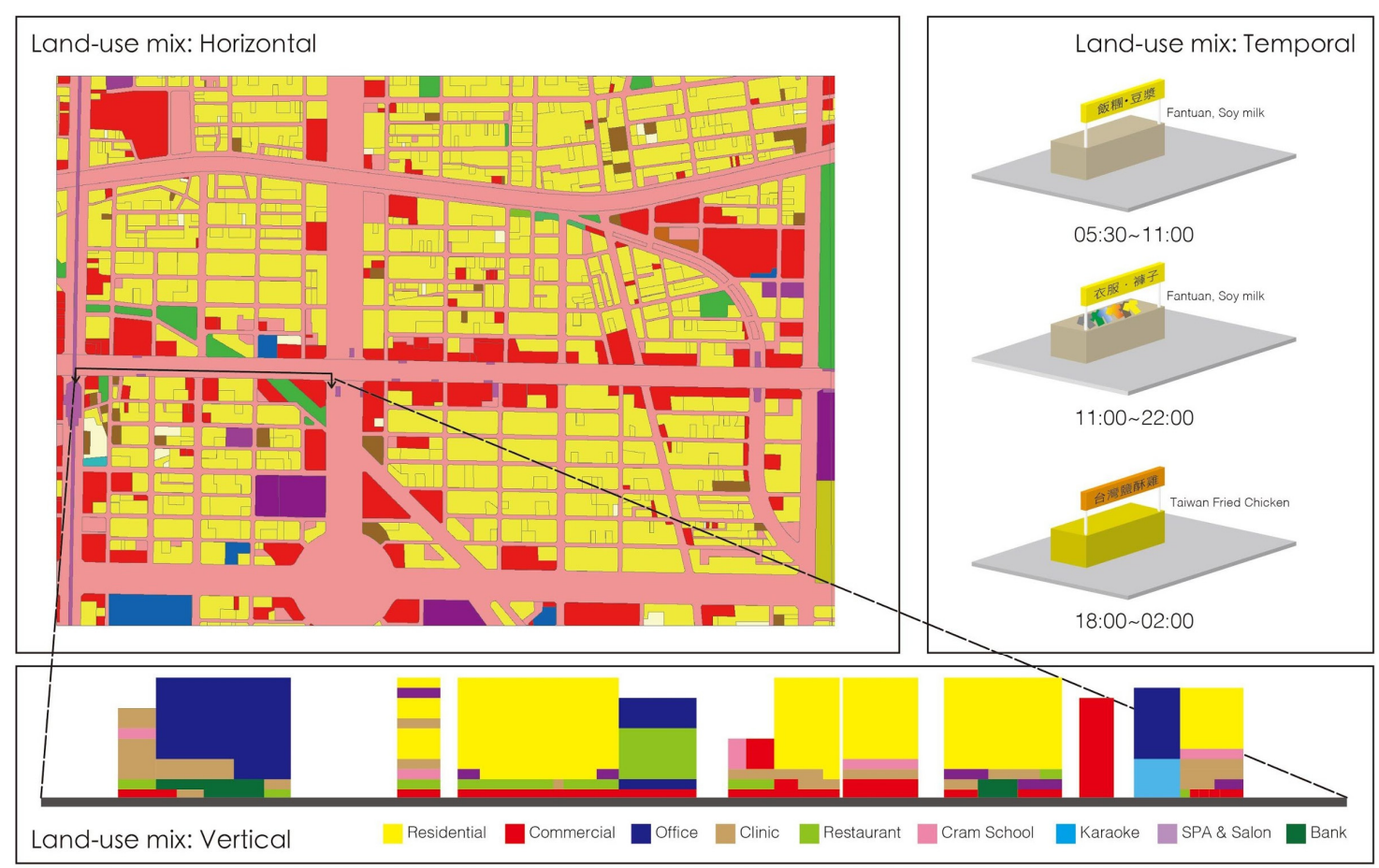

Figure 7. Horizontal, vertical, and temporal land use mix patterns in Asian cities. 


\section{Discussion}

\subsection{Comparison of Population Density, Economic Status, Energy Consumption, and GHG Emissions} by Regions

Comparing the relationship among $\mathrm{CO}_{2}$ emissions, population density (the data of population density is extracted from World Bank report [62] and the UITP (International Union of Public Transport) [66]. According to the World Bank report, there are various definitions of city including administrative boundaries (e.g., a Government Administered Area) and functional boundaries (e.g., a city, metropolitan area, city and county, etc.). However, the definition of city developed by the UITP a built-up high density area. Therefore, in order to conduct comparative analysis between variables, this article is based upon the built-up area density to do further discussion), transport energy use, and Gross Domestic Product (GDP) in Western and Asian cities, there is a distinct difference by region.

On the macro-scale, it shows an inverse correlation between population density and $\mathrm{CO}_{2}$ emissions, that is, $\mathrm{CO}_{2}$ emissions are estimated to be lower in the higher population density cities due to the relatively shorter distances to travel and reductions in energy demand [83]. Such an inverse correlation is weaker in U.S. cities $[15,84]$, and the results show that American cities have the steepest gradient among all selected samples (see Figure $8 \mathrm{~A}$ ). To compare cities by region, the $\mathrm{CO}_{2}$ emissions in American cities are much higher than in East Asian cities (by 1-2.5 times). The results show that density and $\mathrm{CO}_{2}$ emissions may not show as positive a correlation as the IPCC report proposed.

Figure $8 \mathrm{~B}$ shows a similar correlation between population density and transport energy use. The slope of the American region is also much steeper than in other regions. In fact, the relatively low gasoline price might be the main factor causing such a steep gradient between transport energy use and population density in the U.S. [84]. The relative lower gasoline price might increase the driving willingness and such willingness might affect both the frequency and quantity of gasoline usage. Moreover, since the population rapidly increased in the $20^{\text {th }}$ century in the U.S., the transportation infrastructure became focused on automobiles, which is why a lot of wide roads were built. Therefore, the urban sprawl issue might be even worse in U.S. cities $[85,86]$. The $\mathrm{CO}_{2}$ emissions of American cities are estimated to be more than 3000 tons per capita. Comparing Figure $8 \mathrm{~A}, \mathrm{~B}$, the $\mathrm{CO}_{2}$ emissions in East Asian cities are still much lower than those of American cities (1/8-1/4). Furthermore, the $\mathrm{CO}_{2}$ emissions of East Asian cities are lower than those in Southeast Asian and Chinese cities, which suggests that the population density and urban development status in the East Asian cities could support more diverse public transit [87].

Figure $8 \mathrm{C}, \mathrm{D}$ display the relationship among $\mathrm{GDP}, \mathrm{CO}_{2}$, emissions and population density. There are two patterns revealed in Figure 8: a higher GDP with low population density and a high GDP with a comparatively higher population density. The results indicate that most of the relationship between GDP and CO2 emissions is positive, suggesting that higher incomes lead to higher emissions [88]. Indeed, rising incomes leads to decentralization based upon the trade-off between land rent and commute cost [89,90], while it is also possible to become a compact city, which is happening in the East and Southeast Asian cities. Although the GDP in American, European, and East Asian cities is similar (except for Taipei, Hong Kong, and Seoul), the East Asian cities have higher densities than the cities in the US (3-13 times) and Europe (1.5-6.5 times) (see Figure 8C). In addition, there are different trends between GDP and $\mathrm{CO}_{2}$ emissions in each region (see Figure 8D). American, European, and East Asian cities have similar degrees of GDP; however, East Asian cities have lower GHG emissions than Europe (2-4 times) and the United States (4-10 times).

The comparative analysis shows that although American, European, and East Asian cities have similar degrees of GDP, the different urban form might result in different GHG emissions. Both Chinese and Southeast Asian cities have relatively high population density, and the decrease of population density in these cities might implicate that they are undergoing a similar urbanization process to that of Western cities due to their rising incomes. Therefore, there should be caution towards the potential lock-in trends of urban development patterns in Chinese and Southeast Asian cities. 


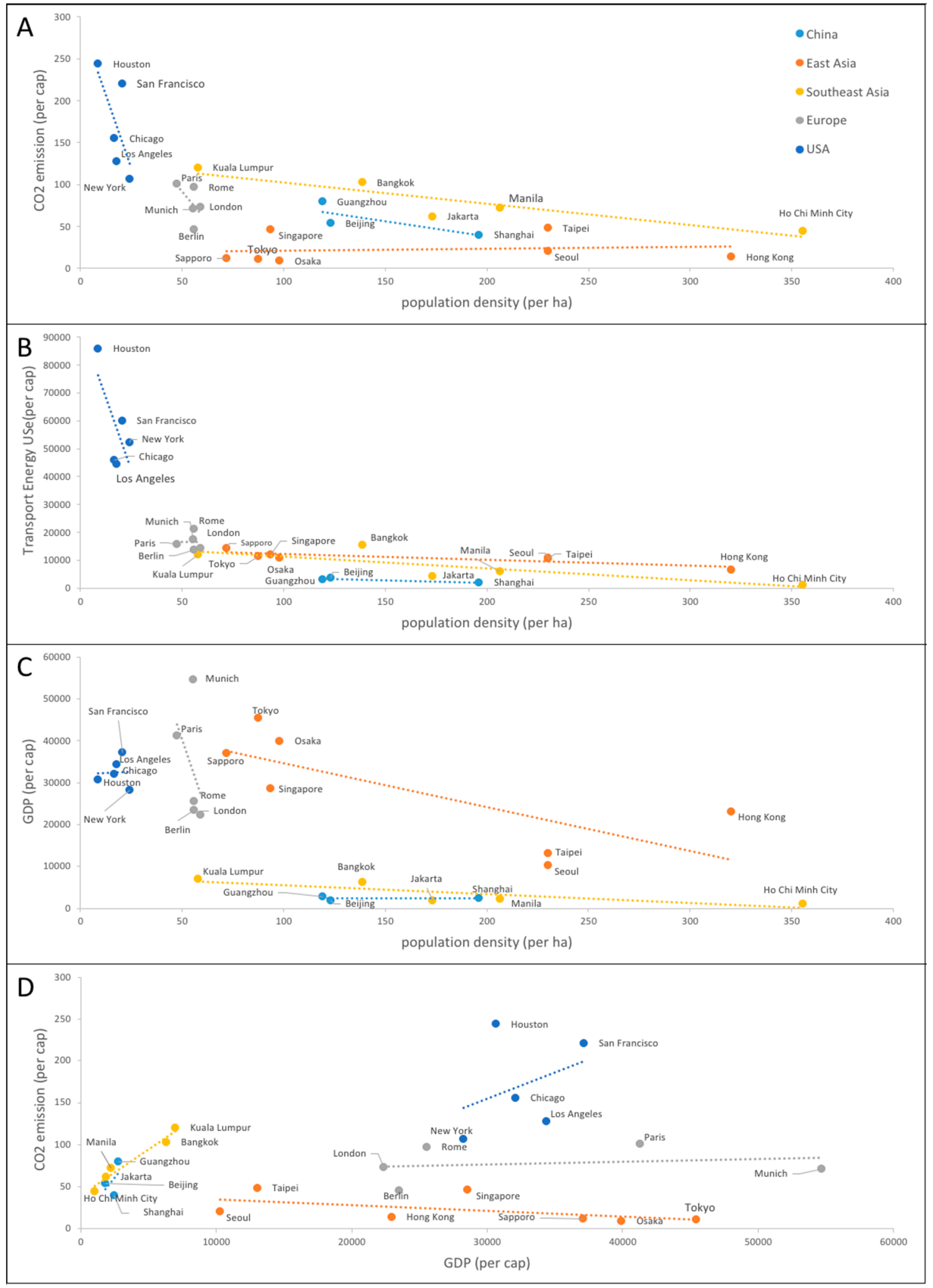

Figure 8. The relationship between population density, CO2 emission, transport energy use, and GDP by regions (References [62,66]). 


\subsection{Urban Form, Planning Systems and Developing Periods in EA and SEA}

Urban form has been shaped by the planning system, cultural background, social norms, and economic development over time. In the context of this study, the urban form characteristics can be grouped into three class by their planning institution, developing process, and period of economic growth (Figure 9).

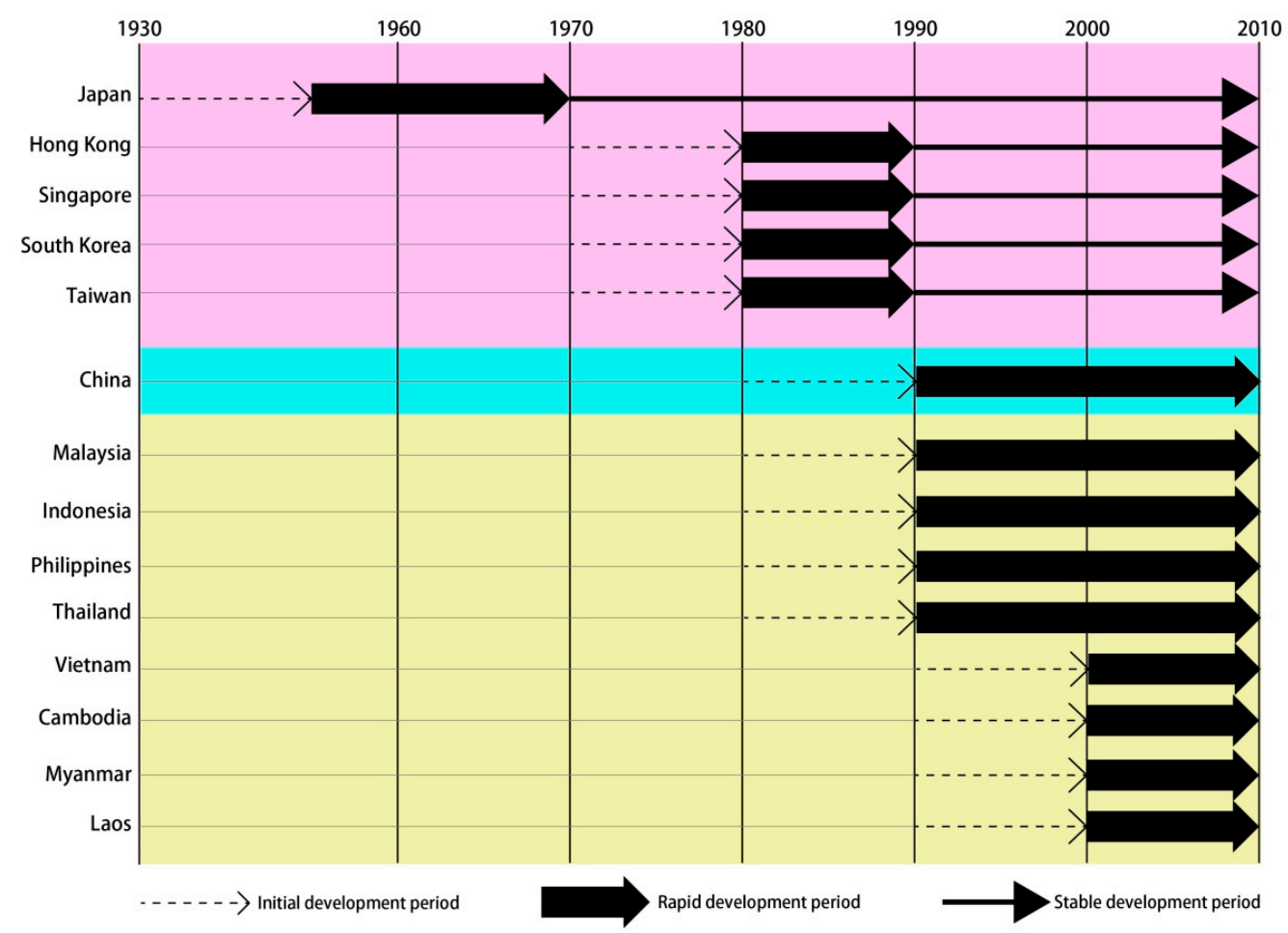

Figure 9. Periods of economic development and urban growth in East Asia and Southeast Asia.

Hong Kong, Singapore, South Korea, and Taiwan are well-known as the "Four Asian Tigers" due to their high-growth economies since the 1960s. With the development of exports and rapid industrialization, the infrastructure and transportation of megacities in the Four Asian Tigers were rapidly transformed in favor of serving urban growth and immigration from the 1970s to 1980s. The Four Asian Tigers' cities have typical urban form characteristics with densely populated areas and land use diversity, and even have more well-developed transportation systems than other Asian cities.

China and "Tiger Cub Economies" (Indonesia, Malaysia, the Philippines, and Thailand) have started their own booming periods since the end of the 1980s. The so-called 'Association of Southeast Asian Nations (ASEAN-4; same as the Tiger Cub Economies)' represents the new economic generation and has experienced a similar but slower growth track of industrializing economies as the original Four Tigers in the early 21st century. The possible emergence of new economies in China and the Tiger Cub Economies may have an influence on the reform of urban patterns in the next decades.

Though the development periods are similar in China and Southeast Asia, urban patterns are different due to the planning system and development process. Chinese cities have been developed in the frame of administrative boundaries; in contrast, the local governments in Southeast Asia are relatively weak in governing urban development. Therefore, cities in Southeast Asia are not compact and sustainable due to leapfrogging and urban sprawl. GHG emissions in Southeast Asian cities are accordingly higher than in Chinese cities. The planning systems in China and Southeast Asian can be further described as follows.

China has a strong governance system and developed a decentralized structure over the past decades, as most Chinese cities were rapidly developing and demonstrating economic development 
and urban growth. The basic concept and general principles underpinning these shifts were developed by the central government for establishing national policies, approving urban master plans, applying rural/urban land conversion, and providing financial support. Municipal governments, however, are all-purpose governments that are responsible for the local economy, employment, and the provision and management of municipal services. In China, urban population density has increased dramatically over the past three decades due to rapid urbanization and industrialization. The huge migration population directly impacts on planned population targets and results in actual urban functional area expansions beyond jurisdictional boundaries. The existing system of local governance, municipal finance, and land-use planning has a major effect on the development of the urban form in China [91].

Increasing dependence on private vehicles is a major source of GHG emissions in Southeast Asian cities. Although car ownership per capita is still low, growing car ownership continues in urban areas. Large population migration into cities is another critical issue. However, most Southeast Asian local authorities lack the mandate and human capacity to handle urban planning and its enforcement mechanisms [92]. Southeast Asian cities are facing the problem of weak capacity of the local or municipal government, which is resulting in a lack of vision and planning implementation [93,94]. From the "under development" stage, planning in Southeast Asian cities is generally short-term, physically oriented, and unable to respond effectively to environmental change. For developing cities to grow in an efficient way, there is an urgent need to strengthen an effective plan for implementation because of the lack of institutional capabilities (e.g., outdated and inefficient legislation, regulations, and processes in a planning system).

\section{Conclusions}

The UN Sustainable Development Summit has declared the "Transforming our world: the 2030 Agenda for Sustainable Development" in 2015 and proposed 17 "Sustainable Development Goals (SDGs)" for 2030 [95]. The urban form has been regarded as a crucial pathway to make cities become more sustainable $[96,97]$. Understanding the urban form characteristics in East and Southeast Asian cities is not only related to the eleventh goal to "make cities and human settlements inclusive, safe, resilient and sustainable", but is also related to achieving the thirteenth goal to "take urgent action to combat climate change and its impacts" from an urban mitigation perspective. In addition, IPCC AR5 has indicated two critical conclusions: Firstly, associated GHG emissions in Asian cities are not different from the ones in developed economies; secondly, economic development is often a major driver of urban GHG emissions that dwarfs the effects of technology choices or place-based policy variables of urban form and infrastructure. Although the basic urban planning strategies of Asian cities follow European or American planning theories, not all of the strategies used have conformed to the cultural background, social norms, and planning systems. In fact, due to various geographical and climate contexts, culture and religion, living style and travel behaviors, governance and institutions, and density and land use mixes demonstrate significant variations in urban form patterns across Western and Asian cities.

In order to have a systematic review of previous relative studies on urban form characteristics, this article applied a systematic review approach to reviewing keywords related to density, land use mix, accessibility, and connectivity. A total of 3725 of records were identified through database searching, and 213 of the studies were included in qualitative analysis. Among the 213 articles, "density" had sufficient data for the systematic review. Due to the limitations, this study only compares density and land use mix among the articles. In fact, the population density might have a more complicated relationship between $\mathrm{CO}_{2}$ emissions, transport energy, and GDP among various kinds of spatial units. However, while the definition of a city varies from country to country, the urban form statistics are extracted from global reports such as World Bank and UITP, and these differences underpin the limitation of this study. Demonstrating how different definitions of administrative boundaries affect urban form statistics remains an area for further research. In addition, urban development might largely be affected by urban economic factors, such as economic activities or governance. 
Although quantitative and qualitative data limitations are an unavoidable restriction in this article, this article still attempted to compare whether Western cities and Asian cities share similar urban form characteristics. The systematic review results reveal that the inconsistency of urban form characteristics exists not only between Western and Asian cities, but also among Asian cities. The systematic review's key findings are as follows:

(1) The decline of annual population density in East and Southeast Asia is significant; population density in the built-up areas has experienced the most dramatic decrease.

(2) Another dominant trend is that population density declined in the core area, but the sub-districts close to the core experienced an increase in population density, which spread towards the edge of the built-up area.

(3) The population density trajectory is different during the urbanization stage, and economic development varies among Asian cities.

(4) Variations in land use mix are conspicuous in Asian cities due to different cultural backgrounds. Therefore, the land-use zoning ordinance is accordingly based on a mixed-use structure.

(5) In addition, it is quite popular to have horizontal, vertical, and temporal mixtures of land use at a given scale.

To sum up, this study highlights that there are large differences between Asian cities and Western cities in urban form regarding density and the land use mix. Both Chinese and Southeast Asian cities have a relatively high population density, while the decrease of population density might implicate that they are undergoing similar urbanization processes to Western cities. Therefore, there should be caution towards exploring the potential for lock-in trends of urban development patterns in Chinese and Southeast Asian cities. Various kinds of horizontal, vertical, and temporal mixtures of land use not only challenge current zoning regulations, but also affect other urban sectors such as transportation. In fact, a compact city might consume more energy $[98,99]$. As a whole, there should be diverse strategies for different regions in future climate change mitigation discussions. This paper focused on discussing the possible lock-in issue in East and Southeast Asian cities, and it is possible to integrate statistic data or remote sensing data to conduct a more thorough discussion of this topic in the future.

Author Contributions: The scope of this study was developed by all three authors. The first manuscript draft was written by T.-L.C., H.-W.C., and Y.-F.L. The database update was conducted by T.-L.C. Most of the figures were developed by H.-W.C. The manuscript has been substantially revised by T.-L.C. and H.-W.C. All authors have read and agreed to the published version of the manuscript.

Funding: This research received no external funding.

Acknowledgments: The authors would like to thank Seto, K. C. for her instruction and the overall lock-in concept.

Conflicts of Interest: The authors declare no conflict of interest.

\section{References}

1. IPCC. AR4 Climate Change 2007: Synthesis Report; IPCC: Geneva, Switzerland, 2007.

2. Seto, K.C.; Dhakal, S.; Bigio, A.; Blanco, H.; Delgado, G.C.; Dewar, D.; Huang, L.; Inaba, A.; Kansal, A.; Lwasa, S.; et al. Human Settlements, Infrastructure and Spatial Planning. In Climate Change 2014: Mitigation of Climate Change. Contribution of Working Group III to the Fifth Assessment Report of the Intergovernmental Panel on Climate Change; Edenhofer, O.R., Pichs-Madruga, Y., Sokona, E., Farahani, S., Kadner, K., Seyboth, A., Adler, I., Baum, S., Brunner, P., Eickemeier, B., et al., Eds.; Cambridge University Press: Cambridge, UK; New York, NY, USA, 2014.

3. Edenhofer, O.; Pichs-Madruga, R.; Sokona, Y.; Kadner, S.; Minx, J.C.; Brunner, S.; Agrawala, S.; Baiocchi, G.; Bashmakov, I.A.; Blanco, G.; et al. Technical Summary. In Climate Change, 2014: Mitigation of Climate Change. Contribution of Working Group III to the Fifth Assessment Report of the Intergovernmental Panel on Climate Change; Edenhofer, O.R., Pichs-Madruga, Y., Sokona, E., Farahani, S., Kadner, K., Seyboth, A., Adler, I., Baum, S., Brunner, P., Eickemeier, B., et al., Eds.; Cambridge University Press: Cambridge, UK; New York, NY, USA, 2014. 
4. Clark, T.A. Metropolitan density, energy efficiency and carbon emissions: Multi-attribute tradeoffs and their policy implications. Energy Policy 2013, 53, 413-428. [CrossRef]

5. VandeWeghe, J.R.; Kennedy, C. A spatial analysis of residential greenhouse gas emissions in the Toronto census metropolitan area. J. Ind. Ecol. 2007, 11, 133-144. [CrossRef]

6. Barla, P.; Miranda-Moreno, L.F.; Lee-Gosselin, M. Urban travel $\mathrm{CO}_{2}$ emissions and land use: A case study for Quebec City. Transp. Res. Part D Transp. Environ. 2011, 16, 423-428. [CrossRef]

7. Minx, J.; Baiocchi, G.; Wiedmann, T.; Barrett, J.; Creutzig, F.; Feng, K.; Hubacek, K. Carbon footprints of cities and other human settlements in the UK. Environ. Res. Lett. 2013, 8, 035039. [CrossRef]

8. Arifwidodo, S.D.; Perera, R. Quality of life and compact development policies in Bandung, Indonesia. Appl. Res. Qual. Life 2011, 6, 159-179. [CrossRef]

9. Hui, E.C.M.; Yu, K.H. Commuting patterns of residents within a high-density urban development: A study of Hong Kong. Habitat Int. 2013, 39, 201-213. [CrossRef]

10. Chen, H.; Jia, B.; Lau, S.S.Y. Sustainable urban form for Chinese compact cities: Challenges of a rapid urbanized economy. Habitat Int. 2008, 32, 28-40. [CrossRef]

11. United Nations. World Urbanization Prospects: The 2018 Revision; United Nations: New York, NY, USA, 2019.

12. Boyko, C.T.; Cooper, R. Clarifying and re-conceptualising density. Prog. Plan. 2011, 76, 1-61. [CrossRef]

13. Bourdic, L.; Salat, S.; Nowacki, C. Assessing cities: A new system of cross-scale spatial indicators. Build. Res. Inf. 2012, 40, 1-14. [CrossRef]

14. Frank, L.D.; Saelens, B.; Powell, K.E.; Chapman, J. Stepping towards ausation: Do built environments or neighborhood and travel preferences explain physical activity, driving, and obesity? Soc. Sci. Med. 2007, 65, 1898-1914. [CrossRef]

15. Ewing, R.; Cervero, R. Travel and the built environment. J. Am. Plan. Assoc. 2010, 76, 265-294. [CrossRef]

16. Mardani, A.; Streimikiene, D.; Cavallaro, F.; Loganathan, N. Carbon dioxide $\left(\mathrm{CO}_{2}\right)$ emissions and economic growth: A systematic review of two decades of research from 1995 to 2017. Sci. Total Environ. 2019, 649, 31-49. [CrossRef] [PubMed]

17. Higgins, J.P.; Altman, D.G.; Gøtzsche, P.C.; Jüni, P.; Moher, D.; Oxman, A.D.; Savovic, J.; Schulz, K.F.; Weeks, L.; Sterne, J.A. Cochrane Bias Methods Group; Cochrane Statistical Methods Group. The Cochrane Collaboration's tool for assessing risk of bias in randomised trials. BMJ 2011, 18, 343.

18. Moher, D.; Liberati, A.; Tetzlaff, J.; Altman, D.G. Preferred reporting items for systematic reviews and meta-analyses: The PRISMA statement. Int. J. Surg. 2009, 8, 336-341. [CrossRef]

19. Sierra-Correa, P.C.; Cantera, J.R. Ecosystem-based adaptation for improving coastal planning for sea-level rise: A systematic review for mangrove coasts. Mar. Policy 2015, 51, 385-393. [CrossRef]

20. Green, S.; Higgins, J. Cochrane Handbook for Systematic Reviews of Interventions. 2015. The Cochrane Collaboration. Available online: http://handbook.cochrane.org/ (accessed on 3 June 2015).

21. Abdullahi, S.; Pradhan, B.; Mansor, S.; Shariff, A.R.M. GIS-based modeling for the spatial measurement and evaluation of mixed land use development for a compact city. GISci. Remote Sens. 2015, 52, 18-39. [CrossRef]

22. Turskis, Z.; Zavadskas, E.K.; Zagorskas, J. Sustainable city compactness evaluation on the basis of GIS and Bayes rule. Int. J. Strateg. Prop. Manag. 2006, 10, 185-207. [CrossRef]

23. Burton, E. Measuring Urban Compactness in UK Towns and Cities. Environ. Plan. B Urban Anal. City Sci. 2002, 29, 219-250. [CrossRef]

24. Thinh, N.X.; Arlt, G.; Heber, B.; Hennersdorf, J. Evaluation of urban land use structure with a view to sustainable development. Environ. Impact Assess. Rev. 2002, 22, 475-492. [CrossRef]

25. Charoentrakulpeeti, C.; Sajor, E.; Zimmermann, W. Middle-class Travel Patterns, Predispositions and Attitudes, and Present-day Transport Policy in Bangkok, Thailand. Transp. Rev. 2006, 26, 693-712. [CrossRef]

26. Bao, D.; Deng, W. The application of job accessibility measure model in China's major cities. In Proceedings of the 2011 International Conference on Transportation, Mechanical, and Electrical Engineering (TMEE), Chang Chun, China, 16-18 December 2011.

27. Chiu, R.L.H. Urban sustainability and the urban forms of China's leading Mega cities: Beijing, Shanghai and Guangzhou. Urban Policy Res. 2012, 30, 359-383. [CrossRef]

28. Liu, Y. Urban villages under China's rapid urbanization: Unregulated assets and transitional neighbourhoods. Habitat Int. 2010, 34, 135-144. [CrossRef]

29. Qin, Z.; Zhang, P. Simulation analysis on spatial pattern of urban population in Shenyang City, China in Late 20th century. Chin. Geogr. Sci. 2011, 21, 110-118. [CrossRef] 
30. Bolay, J.; Cartoux, S.; Cunha, A.; Du, T.T.N.; Bassand, M. Sustainable development and urban growth: Precarious habitat and water management in Ho Chi Minh City, Vietnam. Habitat Int. 1997, 21, 185-197. [CrossRef]

31. Murakami, A.; Zain, A.M.; Takeuchi, K.; Tsunekawa, A.; Yokota, S. Trends in urbanization and patterns of land use in the Asian mega cities Jakarta, Bangkok, and Metro Manila. Landsc. Urban Plan. 2005, 70, 251-259. [CrossRef]

32. Han, H.; Yang, C.; Wang, E.; Song, J.; Zhang, M. Evolution of jobs-housing spatial relationship in Beijing Metropolitan Area: A job accessibility perspective. Chin. Geogr. Sci. 2015, 25, 375-388. [CrossRef]

33. Loo, B.P.; Chow, A.S. Changing urban form in Hong Kong: What are the challenges on sustainable transportation? Int. J. Sustain. Transp. 2008, 2, 177-193. [CrossRef]

34. Jun, M.J.; Kim, J.I.; Kwon, J.H.; Jeong, J.E. The effects of high-density suburban development on commuter mode choices in Seoul, Korea. Cities 2013, 31, 230-238. [CrossRef]

35. Chan, E.H.; Tang, B.S.; Wong, W.S. Density control and the quality of living space: A case study of private housing development in Hong Kong. Habitat Int. 2002, 26, 159-175. [CrossRef]

36. Lin, G.C. The growth and structural change of Chinese cities: A contextual and geographic analysis. Cities 2002, 19, 299-316. [CrossRef]

37. Schneider, A.; Mertes, C.M.; Tatem, A.J.; Tan, B.; Sulla-Menashe, D.; Graves, S.J.; Schelly, I.H. A new urban landscape in East-Southeast Asia, 2000-2010. Environ. Res. Lett. 2015, 10, 034002. [CrossRef]

38. Cerin, E.; Macfarlane, D.J.; Ko, H.H.; Chan, K.C.A. Measuring perceived neighbourhood walkability in Hong Kong. Cities 2007, 24, 209-217. [CrossRef]

39. Abe, R.; Kato, H. Effect of built environment on gasoline consumption in a developing megacity: Evidence from the Jakarta, Indonesia, metropolitan area. Transp. Res. Rec. 2014, 2454, 12-19. [CrossRef]

40. Zhu, J.; Simarmata, H.A. Formal land rights versus informal land rights: Governance for sustainable urbanization in the Jakarta metropolitan region, Indonesia. Land Use Policy 2015, 43, 63-73. [CrossRef]

41. Sorensen, A. Land readjustment and metropolitan growth: An examination of suburban land development and urban sprawl in the Tokyo metropolitan area. Prog. Plan. 2000, 53, 217-330. [CrossRef]

42. Ahmed, Q.I.; Lu, H.; Ye, S. Urban transportation and equity: A case study of Beijing and Karachi. Transp. Res. Part A Policy Pract. 2008, 42, 125-139. [CrossRef]

43. Angel, S.; Parent, J.; Civco, D.L. The fragmentation of urban landscapes: Global evidence of a key attribute of the spatial structure of cities, 1990-2000. Environ. Urban. 2012, 24, 249-283. [CrossRef]

44. Cerin, E.; Lee, K.Y.; Barnett, A.; Sit, C.H.; Cheung, M.C.; Chan, W.M. Objectively-measured neighborhood environments and leisure-time physical activity in Chinese urban elders. Prev. Med. 2013, 56, 86-89. [CrossRef]

45. Chen, Y.; Feng, J. Fractal-based exponential distribution of urban density and self-affine fractal forms of cities. Chaos Solitons Fractals 2013, 45, 1404-1416. [CrossRef]

46. Hui, E.C.M.; Lam, M.C.M. A study of commuting patterns of new town residents in Hong Kong. Habitat Int. 2005, 29, 421-437. [CrossRef]

47. Jo, H. Impacts of urban greenspace on offsetting carbon emissions for middle Korea. J. Environ. Manag. 2002, 64, 115-126. [CrossRef] [PubMed]

48. Lau, J.C.Y. Accessibility and the coping behaviour of the non-employed people in Hong Kong. Habitat Int. 2006, 30, 1047-1055. [CrossRef]

49. Lau, J.C.Y. Sustainable urban transport planning and the commuting patterns of poor workers in a historic inner city in Guangzhou, China. Habitat Int. 2013, 39, 119-127. [CrossRef]

50. Lee, J.; Kurisu, K.; An, K.; Hanaki, K. Development of the compact city index and its application to Japanese cities. Urban Stud. 2014, 52, 1054-1070. [CrossRef]

51. Loo, B.P.Y.; Lam, W.W.Y. Does neighbourhood count in affecting children's journeys to schools? Child. Geogr. 2015, 13, 89-113. [CrossRef]

52. Maleki, M.Z.; Zain, M.F.M.; Ismail, A. Variables communalities and dependence to factors of street system, density, and mixed land use in sustainable site design. Sustain. Cities Soc. 2012, 3, 46-53. [CrossRef]

53. Ortega, A.A.C. Mapping Manila's Mega-Urban Region. Asian Popul. Stud. 2014, 10, 208-235. [CrossRef]

54. Schneider, A.; Woodcock, C.E. Compact, Dispersed, Fragmented, Extensive? A Comparison of Urban Growth in Twenty-five Global Cities Using Remotely Sensed Data, Pattern Metrics and Census Information. Urban Stud. 2008, 45, 659. [CrossRef] 
55. Shyr, O.; Andersson, D.E.; Wang, J. Where Do Home Buyers Pay Most for Relative Transit Accessibility? Hong Kong, Taipei and Kaohsiung Compared. Urban Stud. 2013, 50, 2553-2568. [CrossRef]

56. Sung, H.; Oh, J. Transit-oriented development in a high-density city: Identifying its association with transit ridership in Seoul, Korea. Cities 2011, 28, 70-82. [CrossRef]

57. Tong, C.O.; Wong, S.C. The advantages of a high density, mixed land use, linear urban development. Transportation 1997, 24, 295-307. [CrossRef]

58. Tsou, K.W.; Cheng, H.T. The effect of multiple urban network structures on retail patterns-A case study in Taipei, Taiwan. Cities 2013, 32, 13-23. [CrossRef]

59. Yin, Y.; Mizokami, S.; Maruyama, T. An analysis of the influence of urban form on energy consumption by individual consumption behaviors from a microeconomic viewpoint. Energy Policy 2013, 61, 909-919. [CrossRef]

60. Zhang, M. The Role of Land Use in Travel Mode Choice: Evidence from Boston and Hong Kong. J. Am. Plan. Assoc. 2007, 70, 344-360. [CrossRef]

61. Zhang, Q.; Hu, Y.; Liu, J.; Liu, Y.; Ren, W.; Li, J. A quantitative assessment of the distribution and extent of urban clusters in China. J. Geogr. Sci. 2012, 22, 137-151. [CrossRef]

62. Zhao, P. Sustainable urban expansion and transportation in a growing megacity: Consequences of urban sprawl for mobility on the urban fringe of Beijing. Habitat Int. 2010, 34, 236-243. [CrossRef]

63. Kennedy, C.A.; Ramaswami, A.; Carney, S.; Dhakal, S. Greenhouse gas emission baselines for global cities and metropolitan regions. In Cities and Climate Change: Responding to an Urgent Agenda; The World Bank: Washington, DC, USA, 2011; pp. 15-54.

64. Zhao, P.; Lu, B.; Linden, G.J.J. The Effects of Transport Accessibility and Jobs-Housing Balance on Commuting Time: Evidence from Beijing. Int. Plan. Stud. 2009, 14, 65-83. [CrossRef]

65. Zhu, J. Development of sustainable urban forms for high-density low-income Asian countries: The case of Vietnam: The institutional hindrance of the commons and anticommons. Cities 2012, 29, 77-87. [CrossRef]

66. Kenworthy, J.; Laube, F. Millenium Cities Database for Sustainable Transport; UITP/ISTP: Brussels, Belgium, 2001.

67. Cerin, E.; Sit, C.H.; Cheung, M.C.; Ho, S.Y.; Lee, L.C.J.; Chan, W.M. Reliable and valid NEWS for Chinese seniors: Measuring perceived neighborhood attributes related to walking. Int. J. Behav. Nutr. Phys. Act. 2010, 7, 84. [CrossRef]

68. Liu, X.; Zhou, J. Spatial pattern of land use and its implications for mode-based accessibility: Case study of Nanjing, China. J. Urban Plan. Dev. 2015, 141, 05014012. [CrossRef]

69. Sung, H.; Lee, S.; Jung, S. Identifying the relationship between the objectively measured built environment and walking activity in the high-density and transit-oriented city, Seoul, Korea. Environ. Plan. B Plan. Des. 2014, 41, 637-660. [CrossRef]

70. Wu, J.; Song, Y.; Liang, J.; Wang, Q.; Lin, J. Impact of mixed land use on housing values in high-density areas: Evidence from Beijing. J. Urban Plan. Dev. 2018, 144, 05017019. [CrossRef]

71. Shih, M.; Chang, H.T.B.; Popper, F.J. Development Rights: Regulating Vertical Urbanism in Taiwan. Plan. Theory Pract. 2018, 19, 717-733. [CrossRef]

72. Lin, J.J.; Shin, T.Y. Does transit-oriented development affect metro ridership? Evidence from Taipei, Taiwan. Transp. Res. Rec. 2008, 2063, 149-158. [CrossRef]

73. Ford, L.R. A model of Indonesian city structure. Geogr. Rev. 1993, 83, 374-396. [CrossRef]

74. Hasibuan, H.S.; Moersidik, S.; Koestoer, R.; Soemardi, T.P. Using GIS to integrate the analysis of land use, transportation, and the environment for managing urban growth based on transit oriented development in the metropolitan of Jabodetabek, Indonesia. In Proceedings of the IOP Conference Series: Earth and Environmental Science, Jakarta, Indonesia, 23-24 January 2014; Volume 18, p. 012177.

75. Dharmowijoyo, D.B.; Susilo, Y.O.; Karlström, A. On complexity and variability of individuals' discretionary activities. Transportation 2018, 45, 177-204. [CrossRef]

76. Mahtta, R.; Mahendra, A.; Seto, K.C. Building up or spreading out? Typologies of urban growth across 478 cities of 1 million+. Environ. Res. Lett. 2019, 14, 124077. [CrossRef]

77. Adams, M.A.; Frank, L.D.; Schipperijn, J.; Smith, G.; Chapman, J.; Christiansen, L.B.; Hino, A.A.F. International variation in neighborhood walkability, transit, and recreation environments using geographic information systems: The IPEN adult study. Int. J. Health Geogr. 2014, 13, 43. [CrossRef] 
78. Lau, S.S.Y.; Giridharan, R.; Ganesan, S. Multiple and intensive land use: Case studies in Hong Kong. Habitat Int. 2005, 29, 527-546. [CrossRef]

79. Lin, J.J.; Yang, A.T. Does the compact-city paradigm foster sustainability? An empirical study in Taiwan. Environ. Plan. B Plan. Des. 2006, 33, 365-380. [CrossRef]

80. Wang, S.H.; Huang, S.L.; Huang, P.J. Can spatial planning really mitigate carbon dioxide emissions in urban areas? A case study in Taipei, Taiwan. Landsc. Urban Plan. 2018, 169, 22-36. [CrossRef]

81. Zacharias, J.; Zhang, T.; Nakajima, N. Tokyo Station City: The railway station as urban place. Urban Des. Int. 2011, 16, 242-251. [CrossRef]

82. Yang, H.J.; Song, J.; Choi, M.J. Measuring the externality effects of commercial land use on residential land value: A case study of Seoul. Sustainability 2016, 8, 432. [CrossRef]

83. Newman, P.; Kenworthy, J. Gasoline consumption and cities: A comparison of U. S. cities with a global survey. J. Am. Plan. Assoc. 1989, 55, 24-37. [CrossRef]

84. Creutzig, F.; Baiocchi, G.; Bierkandt, R.; Pichler, P.; Seto, K.C. Global typology of urban energy use and potentials for an urbanization mitigation wedge. PNAS 2014, 112, 1-6. [CrossRef]

85. Borck, R.; Brueckner, J.K. Optimal energy taxation in cities. J. Assoc. Environ. Resour. Econ. 2018, 5, 481-516. [CrossRef]

86. Creutzig, F. How fuel prices determine public transport infrastructure, modal shares and urban form. Urban Clim. 2014, 10, 63-76. [CrossRef]

87. Bongardt, D.; Creutzig, F.; Hüging, H.; Sakamoto, K.; Bakker, S.; Gota, S.; Böhler-Baedeker, S. Low-Carbon Land Transport-Policy Handbook; Routledge: London, UK, 2013; ISBN 978-1-84971-377-1.

88. Khoshnevis Yazdi, S.; Dariani, A.G. $\mathrm{CO}_{2}$ emissions, urbanisation and economic growth: Evidence from Asian countries. Econ. Res. Ekonomska istraživanja 2019, 32, 510-530. [CrossRef]

89. Jones, C.; Watkins, C. Housing Markets E Planning Policy; Blackwell: Oxford, UK, 2009.

90. O'Sullian, A. Urban Economics; McGraw-Hill Education: New York, NY, USA, 2011.

91. Liu, Z.; Salzberg, A. Developing low-carbon cities in China: Local governance, municipal finance, and land use planning-The key underlying drivers. In Sustainable Low-Carbon City Development in China; The World Bank: Washington, DC, USA, 2012; p. 97.

92. Asian Development Bank (ADB). Managing Asian Cities; ADB: Mandaluyong, Philippines, 2008.

93. Hudalah, D.; Winarso, H.; Woltjer, J. Peri-urbanisation in East Asia: A new challenge for planning? Int. Dev. Plan. Rev. 2007, 29, 503-519. [CrossRef]

94. Yuen, B.; Kong, L. Climate change and urban planning in Southeast Asia. Surv. Perspect. Integr. Environ. Soc. 2009, 2.

95. United Nations. Sustainable Development Goals (SDGs). Available online: https://translate.google.com/ translate?hl=zh-TW\&sl=en\&u=https://sustainabledevelopment.un.org/\%3Fmenu\%3D1300\&prev=search (accessed on 10 February 2020).

96. Glaeser, E.L.; Kahn, M.E. The greenness of cities: Carbon dioxide emissions and urban development. J. Urban Econ. 2010, 67, 404-418. [CrossRef]

97. Weisz, H.; Steinberger, J. Reducing energy and material flows in cities. Curr. Opin. Environ. Sustain. 2010, 2, 185-192. [CrossRef]

98. Larson, W.; Yezer, A. The energy implications of city size and density. J. Urban Econ. 2015, 90, 35-49. [CrossRef]

99. Larson, W.; Liu, F.; Yezer, A. Energy footprint of the city: Effects of land use and transportation policies. J. Urban Econ. 2012, 72, 147-159. [CrossRef]

(C) 2020 by the authors. Licensee MDPI, Basel, Switzerland. This article is an open access article distributed under the terms and conditions of the Creative Commons Attribution (CC BY) license (http://creativecommons.org/licenses/by/4.0/). 